\title{
Multiple sclerosis: What have we learned?
}

Steven Karceski, MD

In their article, "Gray matter involvement in multiple sclerosis," Dr. Istvan Pirko and his coauthors review recent information about multiple sclerosis (MS) (Neurology 2007;68:634-642). Most research focuses on how MS affects the myelin-a substance that coats the nerves and is mainly made of fat. The authors of this article describe what MS does to the nerve cell bodies (gray matter, see below) of the brain. Although research is always going on in this area, there is more research to show that involvement of the gray matter predicts the injury that can occur in MS.

\section{What is gray matter and white matter?}

Brain cells are called neurons. Neurons are made up of a cell body. In the brain (and spinal cord), the cell bodies are grouped together in organized ways. When looking at the brain with the naked eye, these groups of cell bodies have a grayish color, and so they are called gray matter.

The outer layer of the brain is one area where cell bodies are grouped together; this region of gray matter is called the cerebral cortex. Deeper in the brain are other groups of cell bodies. These are also called gray matter but they are separate from the cerebral cortex and are called nuclei. The two areas of gray matter are connected together in many ways. The connections between these areas allow us to speak and think.

Nerve cells talk to each other using electrical and chemical signals. These signals must be sent very fast. In order for this to occur, cells must be connected by "wires." These wires are like long threads that extend from the nerve cell body. These threads are called axons. Some axons are short and travel from one part of the brain to another. Others are very long, and travel from the brain to the spinal cord. Some nerve cells are several meters long.

Electrical signals travel much faster through wires that are coated or insulated. This prevents them from short-circuiting. Axons are coated with a substance called myelin which allows for fast movement of signals from one area of the brain to another, or from one part of the body to another. Like gray matter, axons are also grouped together. Because myelin appears white to the naked eye, parts of the brain or spinal cord that are made up of axons are called white matter.

\section{Imaging and the brain}

Experts are able to carefully study the living brain by taking pictures of the brain by using MRI. These methods are always getting better so clearer pictures can be taken and now experts can see shrinking that occurs in the gray matter. Newer MRIs can look at brain function and brain structure. Magnetic resonance spectroscopy (MRS) is another process that experts use to see certain proteins in the brain. One protein is called $\mathrm{N}$-acetylaspartate (NAA). NAA occurs only in nerve cells. In people with MS, the amount of NAA is reduced. Reduced NAA means neuronal loss and shrinking. In other words, scientists can use MRS to show what happens to gray matter in people with MS.

Functional MRI ( $\mathrm{fMRI}$ ) is a new technology that can measure specific brain functions. During this test, a person performs a specific task like reading. $f M R I$ shows the areas of brain that are active while reading. In a normal person, several areas would light up on fMRI. fMRI in a person with MS shows that fewer areas light up. In other words, fMRI highlights where MS affects that gray matter.

\section{Why is this important?}

Thinking occurs in the gray matter. A disease that changes gray matter can harm thinking, memory, and judgment. Some studies show that gray matter shrinking leads to problems with thinking. Many people with MS say that they have poor memory or trouble thinking clearly. MS causes gray matter problems more often in the gradually progressive form of MS. People who have this form are more likely to have permanent disability. Seeing shrinking or atrophy on MRI means that there is some disability.

\section{Where is research going?}

The cause of MS is still not clear. A better understanding of how MS affects the brain and spinal cord may provide this answer. Newer studies look at the living brain using new methods. In combination with studies that look at the brain through a microscope, we may be able to find the cause of MS. Only by understanding the cause can we develop a cure. 


\section{What is MS?}

MS is a disease of the CNS (the brain and spinal cord). It affects women about twice as often as men. It usually starts at age 30 .

The cause of MS is unknown. However, there are several clues about how MS begins. For instance, MS occurs more often in people who live in northern areas. Some experts believe that northerners had a bacteria or virus when they were children. The immune system-cells and organs in our bodies that fight infections-forms antibodies to the bacteria or virus.

Later in life, for reasons that are not known, the antibodies attach to a protein in the myelin coating of the axons. The body becomes confused, and begins destroying the much-needed myelin. Without myelin, nerve cell signals travel much more slowly. This results in weakness, numbness, and other symptoms.

Something in our genes may be responsible for MS. For instance, MS is more likely to occur in firstdegree relatives (mom, dad, brother, or sister) than in distant relatives or unrelated individuals. Twenty-five percent of identical twins, who have identical genetic makeup, develop MS. In compari- son, only $2 \%$ of fraternal twins, whose genetic makeup is like a brother or sister, develop MS.

The genetic research in MS focuses on how our bodies are able to recognize unfamiliar things. For instance, if someone receives a liver transplant, the immune system may see the new liver as foreign and reject it. Research into the genetics of MS may show how some people's bodies become confused. This would help experts figure out who may develop MS, where the body attacks its own myelin.

Most people think MS is an illness that mostly affects white matter. Studies show that MS affects gray matter as well. When MS affects gray matter, the nerve cells die. Nerve cell death causes a decrease in the volume of the gray matter. A reduction in volume is called atrophy. Years ago, before MRI, an autopsy might show atrophy. Today, MRI can identify atrophy in the living brain. Newer MRIs are able to detect subtle changes even more easily.

If MS primarily affects the white matter, why do nerve cells die? Some scientists believe that an attack on myelin also affects the axon. Some nerve cells cannot live without their axons. When a nerve cell dies due to axonal injury, it is called Wallerian degeneration.

Some experts think that MS affects the nerve cell body directly. In other words, the nerve cell body is destroyed first. Which is correct? Is it the axon first, or is an attack on the cell body the beginning of what we call MS? The answer to this question could lead to a cure of this illness.

There are several types of MS. In one, the symptoms come and go. In between the symptoms, the person may feel fine. This type of MS is called relapsing-remitting MS. The other main type is called progressive MS. This type slowly worsens, resulting in a gradual loss of neurologic function. Some have observed that white matter is more involved in the relapsing-remitting type, while gray matter may be more involved in the gradually progressive form.

Are they separate illnesses? Do they overlap? The answers to these questions remain unclear. More research into this complex area is needed.

\section{For more information}

For more information, visit the National Multiple Sclerosis Society at http://www.nationalmssociety.org. 


\title{
Neurology
}

\author{
Multiple sclerosis: What have we learned? \\ Steven Karceski \\ Neurology 2007;68;E9-E10 \\ DOI 10.1212/01.wnl.0000257910.28299.ac
}

This information is current as of February 26, 2007

\section{Updated Information \&} Services

\section{Supplementary Material}

Permissions \& Licensing

Reprints including high resolution figures, can be found at: http://n.neurology.org/content/68/9/E9.full

Supplementary material can be found at: http://n.neurology.org/content/suppl/2007/11/08/68.9.E9.DC1

Information about reproducing this article in parts (figures,tables) or in its entirety can be found online at:

http://www.neurology.org/about/about_the_journal\#permissions

Information about ordering reprints can be found online: http://n.neurology.org/subscribers/advertise

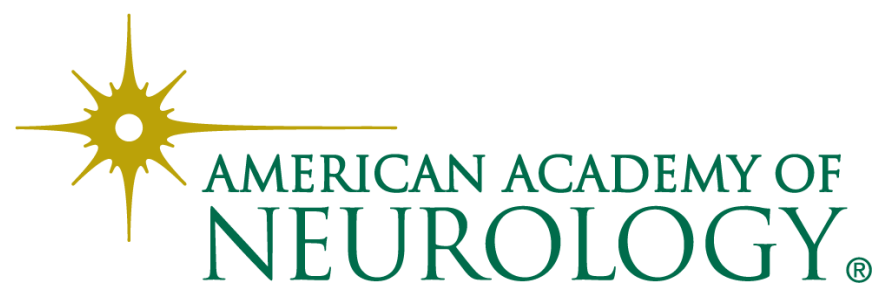

